\title{
Phytoplankton photosynthetic parameters from the Gulf of California southern region
}

\author{
Parámetros fotosintéticos del fitoplancton en la región sur del Golfo de California \\ Gerardo Verdugo-Díaz ${ }^{1}$, Aída Martínez-López ${ }^{1}$, Gilberto \\ Gaxiola-Castro $^{2}$ and José Eduardo Valdez-Holguín ${ }^{3}$
}

\begin{abstract}
${ }^{1}$ Departamento de Plancton y Ecología Marina, Centro Interdisciplinario de Ciencias Marinas, (CICIMAR-I.P.N), Apdo. Postal 592, Av. Instituto Politécnico Nacional S/N Col. Playa Palo de Santa Rita, La Paz, BCS, México, CP 23096. gverdugo@ipn.mx

${ }^{2}$ División de Oceanología, Centro de Investigación Científica y de Educación Superior de Ensenada, Apdo. Postal 2732, Carretera Ensenada-Tijuana No 3918, Zona Playitas, CP 22860, Ensenada BC, México

${ }^{3}$ Departamento de Investigaciones Científicas y Tecnológicas, Universidad de Sonora, Luis Donaldo Colosio S/N, entre Sahuaripa y Reforma Col. Centro, Hermosillo, Sonora, CP 83000, México

Resumen.- Se determinó la respuesta fisiológica del fitoplancton en la zona eufótica por medio de experimentos fotosíntesisirradiancia realizada de junio del 2000 a junio del 2001 en la Bahía de La Paz, Golfo de California, México. Durante el periodo estratificado que comprende de junio a septiembre (índice de estratificación $>200 \mathrm{~J} \mathrm{~m}^{-3}$ ) el número de asimilación $\left(P_{m}\right)$ estuvo representado por un valor promedio de $3,7 \mathrm{mg} \mathrm{C} \mathrm{m}^{-3} \mathrm{~h}^{-1}$, mientras que de noviembre a febrero, cuando la columna de agua fue homogénea (índice de estratificación $=0 \mathrm{~J} \mathrm{~m}^{-3}$ ) fue de $9,2 \mathrm{mg} \mathrm{C} \mathrm{m}^{-3} \mathrm{~h}^{-1}$. La eficiencia fotosintética máxima a baja irradiancia $(\alpha)$ tuvo un valor promedio de $0,017 \mathrm{mg} \mathrm{C} \mathrm{m}^{-3} \mathrm{~h}^{-1}\left(\mu \mathrm{mol} \text { cuanta } \mathrm{m}^{-2} \mathrm{~s}^{-1}\right)^{-1}$ representativo del periodo estratificado, mientras que durante el periodo homogéneo fue de $0,063 \mathrm{mg} \mathrm{C} \mathrm{m}^{-3} \mathrm{~h}^{-1}$ ( $\mu$ mol cuanta $\left.\mathrm{m}^{-2} \mathrm{~s}^{-1}\right)^{-1}$. Los parámetros fotosintéticos (Pm y $\alpha$ ) durante la mayor dinámica de la zona epipelágica evidencian la fotoaclimatación del fitoplancton a la irradiancia promedio en la zona eufótica. Valores altos de $\mathrm{P}_{\mathrm{m}}$ se relacionaron con la abundancia de diatomeas (Pseudo-nitzschia delicatissima, Chaetoceros compressus y Coscinodiscus perforatus), mientras que los valores menores de este parámetro se asociaron con el grupo de los dinoflagelados. Los valores promedio estimados para el parámetro de saturación de luz $\left(E_{k}\right)$ fueron 334, 173 y $91 \mu \mathrm{mol}$ cuanta $\mathrm{m}^{-2} \mathrm{~s}^{-1}$ para superficie, 10 y $1 \%$ de la zona eufótica, respectivamente. De manera general, la comunidad fitoplanctónica estuvo dominada por nanofitoplancton $(2-20 \mu \mathrm{m})$ durante todo el periodo considerado.
\end{abstract}

Palabras clave: Parámetros fotosintéticos, zona eufótica, Golfo de California

Abstract.- Phytoplankton physiologic response in the euphotic zone was determined by photosynthesis-irradiance experiments carried out between June 2000 and June 2001 at Bahia de La Paz, Gulf of California, Mexico. A stratified water column was present, from June to September (stratification index $>200 \mathrm{~J} \mathrm{~m}^{-3}$ ), with the assimilation number $\left(P_{\mathrm{m}}\right)$ represented by an average of $3.7 \mathrm{mg} \mathrm{C} \mathrm{m}^{-3} \mathrm{~h}^{-1}$, while for the period from November through February, the water column was homogeneous (stratification index $=0 \mathrm{~J} \mathrm{~m}^{-3}$ ) and the average was $9.2 \mathrm{mg} \mathrm{C} \mathrm{m}^{-3} \mathrm{~h}^{-1}$. The maximum photosynthetic efficiency at low irradiances $(\alpha)$ of $0.017 \mathrm{mg} \mathrm{C} \mathrm{m}^{-3} \mathrm{~h}^{-1}$ ( $\mu \mathrm{mol}$ quanta $\left.\mathrm{m}^{-2} \mathrm{~s}^{-1}\right)^{-1}$ was the representative average for the stratified period, while $0.063 \mathrm{mg} \mathrm{C}$ $\mathrm{m}^{-3} \mathrm{~h}^{-1}$ ( $\mu \mathrm{mol}$ quanta $\left.\mathrm{m}^{-2} \mathrm{~s}^{-1}\right)^{-1}$ was the corresponding value for the homogeneous period. The photosynthetic parameters $\left(\mathrm{P}_{\mathrm{m}}\right.$ and $\alpha$ ) had an increase during mixing conditions, as result of phytoplankton photoacclimation to average irradiance in the euphotic zone. Diatom abundance (Pseudo-nitzschia delicatissima, Chaetoceros compressus and Coscinodiscus perforatus) were related with higher values of $P_{m}$, while lowest values of this parameter are associated with the dinoflagellate group. Average values estimated for the light saturation parameter $\left(E_{k}\right)$ were 334,173 and $91 \mu$ mol quanta $\mathrm{m}^{-2} \mathrm{~s}^{-1}$ for the surface, 10 and $1 \%$ of the euphotic zone, respectively. In general, nanophytoplankton $(2-20 \mu \mathrm{m})$ dominated the phytoplanktonic community during the period studied.

Key words: Photosynthetic parameters, euphotic zone, Gulf of California

\section{INTRODUCTION}

One of the biological oceanography goals is the determination of the photosynthetic or carbon assimilation rate by phytoplankton (Falkowsky \& Raven
1997). A perspicuous understanding of this complex process that controls marine biogeochemistry is essential, since their interlinked effects span from a regional to a 
global scale. One investigative technique utilized to study this process is the determination of phytoplankton photosynthetic parameters from photosynthesis irradiance (P-E) curves (Jassby \& Platt 1976). These allow the physiological response of the phytoplankton community in the face of environmental variability to be quantified (Coté \& Platt 1983, 1984). The photosynthetic parameters $\alpha$ (maximum light utilization coefficient at low irradiance) and $\mathrm{P}_{\mathrm{m}}$ (maximum photosynthetic rate at light saturation), are related by the following equation: $\mathrm{E}_{\mathrm{k}}=\mathrm{P}_{\mathrm{m}}$ / $\alpha$, where $E_{k}$ is the light-saturation parameter ( $\mu$ mol quanta $\left.\mathrm{m}^{-2} \mathrm{~s}^{-1}\right) ; \mathrm{P}_{\mathrm{m}}$ is the maximum photosynthesis at light saturation (mg C m${ }^{-3} \mathrm{~h}^{-1}$ ) and $\alpha$ is the maximum light utilization coefficient $\left[\mathrm{mg} \mathrm{C} \mathrm{m}^{-3} \mathrm{~h}^{-1}\left(\mu \mathrm{mol} \text { quanta } \mathrm{m}^{-2} \mathrm{~s}^{-1}\right)^{-1}\right.$. These 2 parameters are fundamental to describe photosynthesis-irradiance relationships (Tilzer et al. 1993, Sakshaug et al. 1997).

Phytoplankton photosynthetic parameters variability can be attributed to changes in environmental or growth conditions (Dower \& Lucas 1993), and its delineation can ultimately lead to a better understanding of algal physiology and water column production. In this context, it is necessary to generate 'local specific' data for these photosynthetic parameters. Bahía de La Paz is a unique region due to its climatic regime for the set up and development of algorithms to estimate integrated water column production using phytoplankton P-E parameters. In addition, minimal yearly cloud cover favors the use of satellite color imagery which when combined with these parameters allows primary production to be estimated from satellite data (Platt \& Sathyendranath 1988).

Estimates of primary productivity are necessary to assess the interchange of material comprising the oceanatmosphere $\mathrm{CO}_{2}$ balance. Primary productivity data is sparse for this area of the Gulf of California, and when available it only documents indirect measurements of the photosynthetic rate (i.e.,phytoplankton natural fluorescence) (Reyes-Salinas et al. 2003, CervantesDuarte et al. 2005). Thus, due to the previously noted conditions this study will utilize the variability of photosynthesis-irradiance parameters of phytoplankton in Bahía de La Paz, with the aim of proposing representative average values for different oceanographic conditions, which in turn will allow prediction of photosynthetic production rates (Alvarez-Borrego 2011) based on models like those proposed by Platt \& Sathyendranath (1988).

\section{MATERIALS AND METHODS}

Bahía de La Paz is located in the southeast of the Baja California peninsula, bounded by lines making a polygon connecting the following geographical positions, $24^{\circ} 10^{\prime}-$ $24^{\circ} 47^{\prime} \mathrm{N}$, and $110^{\circ} 20-110^{\circ} 44^{\prime} \mathrm{W}$, covering an approximate area of 2,635 km² (Cruz-Orozco et al. 1989). The bay has a semi-elliptical shape, with its major axis oriented in a northwesterly to southeasterly direction. The bay communicates with the Gulf of California by 2 channels, a northeastern channel (Boca Grande) and another one to the east (Canal de San Lorenzo). During the warm period (May to October), intense solar radiation and the weak sea breezes from the southeast allow a strong stratification in the water column. During the cold season (November to April), strong northwest winds increase the mixed layer depth.

Monthly samplings were conducted at a station $\left(24^{\circ} 29.12^{\prime} \mathrm{N}, 110^{\circ} 28.33^{\prime} \mathrm{W}\right)$ located in the central area of Bahía de La Paz, (Fig.1) from June 2000 to June 2001, except July and December 2000 (Table 1). Samples were collected from 6 depths differentiated by the percentages

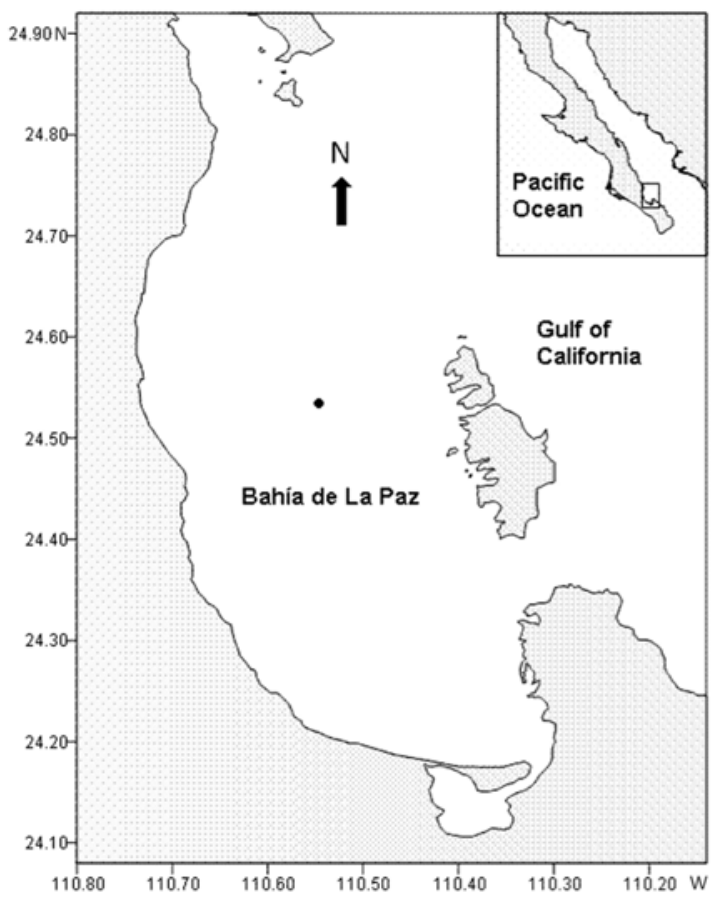

Figure 1. Study area and localization of the sampling station $(\bullet)$ in the southern Gulf of California, México / Área de estudio y localización de la estación de muestreo $(\bullet)$ en el sur del Golfo de California, México 
Table 1. Sampling dates and depths $(m)$ of the surface irradiances percentages / Fechas de muestreo y profundidad $(\mathrm{m})$ de los porcentajes de luz referidos a la irradiancia superficial

\begin{tabular}{cccc}
\hline Date & \multicolumn{3}{c}{ Surface irradiance percentages } \\
$(\mathrm{DD} / \mathrm{MM} / \mathrm{YY})$ & $100 \%$ & $10 \%$ & $1 \%$ \\
\hline $26 / 06 / 00$ & 0 & 10 & 20 \\
$10 / 08 / 00$ & 0 & 30 & 60 \\
$7 / 09 / 00$ & 0 & 29 & 58 \\
$16 / 10 / 00$ & 0 & 27 & 55 \\
$26 / 11 / 00$ & 0 & 20 & 40 \\
$26 / 01 / 01$ & 0 & 20 & 40 \\
$14 / 02 / 01$ & 0 & 20 & 40 \\
$22 / 03 / 01$ & 0 & 17 & 36 \\
$20 / 04 / 01$ & 0 & 20 & 40 \\
$21 / 05 / 01$ & 0 & 14 & 29 \\
$22 / 06 / 01$ & 0 & 14 & 29 \\
\hline
\end{tabular}

of light penetration (100, 55, 33, 10, 3 and $1 \%$ of surface irradiance), calculated using the light attenuation coefficient $\left(\mathrm{K}_{\mathrm{d}}\right)$ determinated by the Secchi disk (Brown et al. 1989). Sampling depths were estimated following Lambert-Beer relationship $Z=(L n E o-L n E z) / K d$. At each depth, water column was collected for taxonomic phytoplankton identification, and dissolved inorganic nutrients analyses. Phytoplankton samples were fixed with acid Lugol's solution (final concentration of 1\%), and analyzed employing the method devised by Utermöhl (Hasle 1978). The phytoplankton taxa were identified according to Hustedt (1930, 1959), Cupp (1943), LicéaDurán (1974) for diatoms; Schiller (1933), Taylor (1976), Pesantes (1978) and Balech (1988) for dinoflagellates and Murray \& Schrader (1983) and Schrader et al. (1986), for silicoflagellates. Hasle \& Syvertsten (1996) and Steindinger \& Tangen (1996) were consulted to review and update in cases of synonymy between species.

The concentration of inorganic nutrients (nitrites and nitrates) was determined according to the methods proposed by Parsons et al. (1984). The properties of the water column were characterized (temperature, salinity) using a CTD (Sea Bird-25). The stratification index proposed by Simpson \& Hunter (1974) was calculated using the temperature, salinity and density data for the upper $50 \mathrm{~m}$ depth. The stratification index $(\varphi)$, interpreted as the amount of mechanical energy required to bring about vertical mixing $\left(\mathrm{J} \mathrm{m}^{-3}\right)$, equals zero for a well-mixed layer and increases with stratification, expressed by the following equation:

$$
\varphi=\frac{1}{h} \int_{-h}^{0}(\bar{\rho}-\rho) \operatorname{gzdz}
$$

where: $\rho$ = seawater density, $\bar{\rho}=$ average seawater density, $\mathrm{g}$ = gravity acceleration $\left(9.81 \mathrm{~m} \mathrm{~s}^{-2}\right), \mathrm{h}=$ depth (in this case $50 \mathrm{~m}$ ), and $\mathrm{z}=$ vertical coordenate (ascendent and positive).

The determination of photosynthetic parameters was carried out by experimental measurements of ${ }^{14} \mathrm{C}$ assimilation during June, September and November of 2000, as well as during February and May of 2001. Water samples were collected from $100 \%, 10 \%$ and $1 \%$ surface irradiance levels, using dark bottles and filtered through a $333 \mu \mathrm{m}$ mesh to remove microzooplankton. Samples were stored in refrigerator while the experiment was prepared. Water samples were collected with a lapse of approximately 1-1.5 h between sample acquisition and the initiation of incubation in the laboratory, where samples were inoculated with $1 \mu \mathrm{Ci}$ of $\mathrm{NaH}^{14} \mathrm{CO}_{3}$. Inoculated samples were incubated during $1 \mathrm{~h}$ in 3 incubators similar to those proposed by Babin et al. (1994). Incubation bottles were the same type as those used for tissue cultures, polystyrene plastic, which have provided good results in the incubation of marine phytoplankton samples; polystyrene doesn't affect the phytoplankton for incubation periods up to $2 \mathrm{~h}$ (Babin et al. 1994). The light source was a $300 \mathrm{~W}$ tungsten-halogen lamp. Care was taken during the incubation process, so that water temperature inside incubators remained approximately equal to the temperature from which the sample was collected $\left( \pm 1^{\circ} \mathrm{C}\right)$. The radioactivity counts in the phytoplankton samples were measured utilizing a Beckman LSC 6500 liquid scintillation counter. The inorganic carbon assimilation was determined following Steemann-Nielsen (1952).

Mathematical model used for the adjustment of the photosynthetic parameters was the proposed by Jassby \& Platt (1976). Nonlinear models from Statistica ver. 7 software were used to simultaneously estimate both parameters $\left(\mathrm{P}_{\mathrm{m}}\right.$ and $\left.\alpha\right)$ using the relationship:

$$
P=P_{m} \tanh \left(\alpha E o / P_{m}\right)
$$

where $\alpha$ is the maximum light coefficient at low irradiance [(mg C m $\left.\left.{ }^{-3} \mathrm{~h}^{-1}\right)\left(\mu \mathrm{mol} \text { quanta } \mathrm{m}^{-2} \mathrm{~h}^{-1}\right)^{-1}\right], \mathrm{P}_{\mathrm{m}}$ is the maximum photosynthesis at light saturation ( $\mathrm{mg} \mathrm{C} \mathrm{m}^{-3} \mathrm{~h}^{-1}$ ), $\mathrm{E}_{\mathrm{o}}$ is the light intensity in the incubator ( $\mu \mathrm{mol}$ quanta $\mathrm{m}^{-2} \mathrm{~s}^{-1}$ ). 


\section{Results}

Water column temperature and the Simpson \& Hunter (1974) stratification index $\left(\varphi ; \mathrm{J} \mathrm{m}^{-3}\right)$ indicated stratification from June through September. This period was characterized by temperature in excess of $28^{\circ} \mathrm{C}$, and high stratification index $\left(>200 \mathrm{~J} \mathrm{~m}^{-3}\right.$ ); while from November to February exhibited a mixed layer depth exceeding $50 \mathrm{~m}$ deep (i.e., zero stratification) and lower temperature. These conditions began to reversal slowly, rising trend starting in March, until the stratification index reached $200 \mathrm{~J} \mathrm{~m}^{-3}$ in June 2001. From this parameter May 2001 was considered a transitional month (Fig. 2).

Phytoplankton abundance was dominated both temporally and spatially by nanophytoplankton (cell size 2-20 $\mu \mathrm{m}$ ), with higher cells abundance recorded at subsurface levels during June and September 2000. The microphytoplankton fraction (cells size $>20 \mu \mathrm{m}$ ) showed their maximum proliferation in June 2000 at the bottom of the euphotic zone (Table 2), with Pseudo-nitzschia delicatissima as the the dominant specie.

Nitrate concentration in the euphotic zone showed a stratified distribution all year. Minimal values $(<2.5 \mu \mathrm{M})$ were associated with the surface layer, mainly during the months of higher water column stratification (from July to September 2000); while maximum values were registered at the deepest levels of the euphotic zone. We observed a nitrate increase at 10 and $1 \%$ irradiance levels mainly during October 2000 and March 2001. Nitrite concentrations in the euphotic zone registered values lower than $0.2 \mu \mathrm{M}$ from June to October 2000. Early in the condition of mixed water column, nitrite concentration gradually increased until its maximum value achieved in March $(1.2 \mu \mathrm{M})$. Subsequently, a decrease was observed during April, May, and June (Table 2).

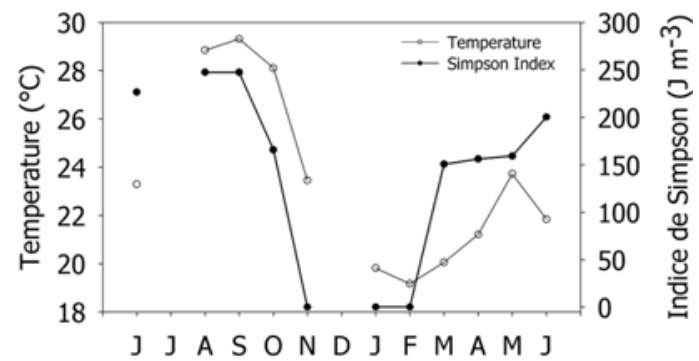

Figure 2. Monthly sea surface temperature and the Simpson and Hunter (1974) stratification index from June 2000 to June 2001 / Variabilidad mensual de la temperatura superficial del mar y el índice de estratificación de Simpson y Hunter (1974) de junio de 2000 a junio de 2001

Table 2. Nano- $(\mathbf{5 - 2 0} \mu \mathrm{m})$ and microphytoplankton $(>\mathbf{2 0} \mu \mathrm{m})$ abundance, and nutrient concentration / Abundancia del nano $(5-20 \mu \mathrm{m})$ y microfitoplancton $(>20 \mu \mathrm{m})$ y concentración de nutrientes

\begin{tabular}{|c|c|c|c|c|c|c|c|c|c|c|c|c|}
\hline \multirow[t]{2}{*}{ Year/Month } & \multicolumn{3}{|c|}{$\begin{array}{l}\text { Nanophytoplankton } \\
\quad\left(10^{3} \text { cells } \mathrm{L}^{-1}\right)\end{array}$} & \multicolumn{3}{|c|}{$\begin{array}{l}\text { Microphytoplankton } \\
\qquad\left(10^{3} \text { cells } \mathrm{L}^{-1}\right)\end{array}$} & \multicolumn{3}{|c|}{$\begin{array}{l}\text { Nitrite } \\
(\mu \mathrm{M})\end{array}$} & \multicolumn{3}{|c|}{$\begin{array}{l}\text { Nitrate } \\
(\mu \mathrm{M})\end{array}$} \\
\hline & $100 \%$ & $10 \%$ & $1 \%$ & $100 \%$ & $10 \%$ & $1 \%$ & $100 \%$ & $10 \%$ & $1 \%$ & $100 \%$ & $10 \%$ & $1 \%$ \\
\hline \multicolumn{13}{|l|}{2000} \\
\hline June & 242.2 & 575 & 201 & 1.4 & 6.2 & 14.40 & 0.010 & 0.010 & 0.020 & 0.480 & 19.08 & 13.10 \\
\hline August & 228 & 245 & 210 & 1.6 & 0.50 & 1 & 0.006 & 0.024 & 0.012 & 0.421 & 3.16 & 10.22 \\
\hline September & 301 & 546.2 & 410 & 1.1 & 1.7 & 0.80 & ND & 0.040 & 0.020 & 0.510 & 3.51 & 7.38 \\
\hline October & 456 & 512 & 486 & 0.5 & 1.3 & 1 & 0.006 & 0.059 & 0.008 & 0.279 & 10.86 & 18.65 \\
\hline November & 385 & 402 & 268 & 1.5 & 1.3 & 1.90 & 0.380 & 0.480 & 0.440 & 3.060 & 2.77 & 4.88 \\
\hline \multicolumn{13}{|l|}{2001} \\
\hline January & 326.2 & 401 & 298.3 & 1.5 & 1 & 0.90 & 0.059 & 0.054 & 0.071 & 2.630 & 2.14 & 3.55 \\
\hline February & 452.3 & 488 & 399.9 & 1.2 & 1.2 & 1 & 0.030 & 0.740 & 0.660 & 22.26 & 5.70 & 15.18 \\
\hline March & 102.8 & 99.2 & 86.4 & 0.9 & 1.1 & 0.40 & 0.060 & 0.042 & 0.063 & 0.360 & 4.03 & 10.01 \\
\hline April & 118 & 108.6 & 99 & 2.6 & 4 & 4.80 & ND & ND & ND & ND & ND & ND \\
\hline May & 62 & 61.6 & 52 & 9.3 & 6.3 & 4.10 & ND & ND & ND & ND & ND & ND \\
\hline June & 206 & 196 & 196.6 & 0.8 & 1.8 & 1 & 0.050 & 0.032 & 0.45 & 0.390 & 13.4 & 7.1 \\
\hline
\end{tabular}

${ }^{*} \mathrm{ND}=$ no data available 
Phytoplankton photosynthetic parameters showed a temporal variability related with oceanographic conditions of the water column. During months of stratification (June and September 2000), maximum photosynthetic efficiency at low irradiances $(\alpha)$ from the 3 levels of the sampled euphotic zone fluctuating between 0.005 and $0.035 \mathrm{mg} \mathrm{C}$ $\mathrm{m}^{-3} \mathrm{~h}^{-1}\left(\mu \mathrm{mol} \text { quanta } \mathrm{m}^{-2} \mathrm{~s}^{-1}\right)^{-1}$, giving a representative mean of $0.017 \mathrm{mg} \mathrm{C} \mathrm{m}^{-3} \mathrm{~h}^{-1}$ ( $\mu \mathrm{mol}$ quanta $\left.\mathrm{m}^{-2} \mathrm{~s}^{1}\right)^{-1}$. During November 2000 and 2001, when the water column was homogeneous, $\left(\varphi \sim 0 \mathrm{~J} \mathrm{~m}^{-3}\right)$, $\alpha$ reached their maxima values [0.052 and $0.115 \mathrm{mg} \mathrm{C} \mathrm{m}^{-3} \mathrm{~h}^{-1}\left(\mu \mathrm{mol} \text { quanta } \mathrm{m}^{-2} \mathrm{~s}^{-1}\right)^{-1}$ ] , and the difference between the 3 sampled levels increase, showing a variation between 0.019 and $0.115 \mathrm{mg} \mathrm{C} \mathrm{m}^{-3} \mathrm{~h}^{-1}$ $\left(\mu \mathrm{mol} \text { quanta } \mathrm{m}^{-2} \mathrm{~s}^{1}\right)^{-1}$. The overall representative average was $0.06 \mathrm{mg} \mathrm{C} \mathrm{m}^{-3} \mathrm{~h}^{-1}\left(\mu \mathrm{mol} \text { quanta } \mathrm{m}^{-2} \mathrm{~s}^{1}\right)^{-1}$. During May considered as a transitional month between homogeneity and stratification conditions, $\alpha$ ranged from 0.005 and 0.007 , with a mean value of $0.006 \mathrm{mg} \mathrm{C} \mathrm{m}^{-3} \mathrm{~h}^{-1}(\mu$ mol quanta $\left.\mathrm{m}^{-2} \mathrm{~s}^{-1}\right)^{-1}$.

Maximum photosynthesis rate $\left(\mathrm{P}_{\mathrm{m}}\right)$ behaved similarly to the previously described parameter. However, its variability between irradiance levels showed more deviation. For the stratification period, $\mathrm{P}_{\mathrm{m}}$ ranged from 0.72 to $8.66 \mathrm{mg} \mathrm{C} \mathrm{m}^{-3} \mathrm{~h}^{-1}$, with a mean of $3.62 \mathrm{mg} \mathrm{C} \mathrm{m}^{-3} \mathrm{~h}^{-1}$. In contrast, this parameter showed markedly higher values during the months of mixed water column $\left(\varphi \sim 0 \mathrm{~J} \mathrm{~m}^{-3}\right)$, ranging between 6.39 and $12.69 \mathrm{mg} \mathrm{C} \mathrm{m}^{-3} \mathrm{~h}^{-1}$, with a representative mean value of $9.3 \mathrm{mg} \mathrm{C} \mathrm{m}^{-3} \mathrm{~h}^{-1}$. During May 2001 the minimum registered value was 0.41 and the maximum 1.72, with an average of $1.14 \mathrm{mg} \mathrm{C} \mathrm{m}^{-3} \mathrm{~h}^{-1}$.

With respect to the light saturation index $\left(\mathrm{E}_{\mathrm{k}}\right)$, the main source of variation was on the vertical coordinate, as this parameter showed evident differences between the considered light levels. Light saturation index at surface registered values between 232 y $469 \mu$ mol quanta $\mathrm{m}^{-2} \mathrm{~s}^{-1}$, with an average of $335 \mu \mathrm{mol}$ quanta $\mathrm{m}^{-2} \mathrm{~s}^{-1}$. In the intermediate level (10\% of surface irradiance), values oscillated between 110 and $247 \mu \mathrm{mol}$ quanta $\mathrm{m}^{-2} \mathrm{~s}^{-1}$, with an average of $173 \mu \mathrm{mol}$ quanta $\mathrm{m}^{-2} \mathrm{~s}^{-1}$. In the lower limit of the euphotic zone ( $1 \%$ of surface irradiance) $E_{k}$ changed between 65 and $119 \mu \mathrm{mol}$ quanta $\mathrm{m}^{-2} \mathrm{~s}^{-1}$, being $91 \mu \mathrm{mol}$ quanta $\mathrm{m}^{-2} \mathrm{~s}^{-1}$ the average value (Table 3). Euphotic zone lowest differences of $E_{k}$ were obtained during November and February (water column mixing conditions), indicating highest phytoplankton photoacclimation to mean irradiance, derived from the lower stratification prevailing during those months.

By correlating the Simpson stratification index $(\varphi)$ with the photosynthetic parameters, we found that the maximum photosynthetic efficiency at low irradiances $(\alpha)$ showed negative slope for the 3 considered light levels, with the determination coefficient $\left(\mathrm{r}^{2}\right)$ between 0.54 and 0.72 . In the same sense, maximum photosynthetic parameter $\left(\mathrm{P}_{\mathrm{m}}\right)$ had a negative linear relationship, with $\varphi$ showing a variation between 0.45 and 0.81 in the determination coefficient. Unlike the 2 previously described parameters, light saturation index $\left(\mathrm{E}_{\mathrm{k}}\right)$ showed positive slope with $\varphi$ at both the surface and the level corresponding to $10 \%$ of surface irradiance, with determination coefficients of 0.46 and 0.81 , respectively. At the lower limit of the euphotic zone, the determination coefficient was higher (0.91), with negative slope.

Table 3. Phytoplankton photosynthetic parameters at 100,10 and $1 \%$ of surface irradiance / Parámetros fotosintéticos del fitoplancton a 100,10 y $1 \%$ de la irradiancia superficial

\begin{tabular}{|c|c|c|c|c|c|c|c|c|c|}
\hline \multirow{3}{*}{ Month } & \multicolumn{9}{|c|}{ Photosynthetic parameters } \\
\hline & \multicolumn{3}{|c|}{ 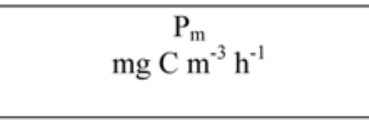 } & \multicolumn{3}{|c|}{$\begin{array}{c}\alpha \\
{\left[\mathrm{mg} \mathrm{C} \mathrm{m}^{-3} \mathrm{~h}^{-1}\right.} \\
\left.\left(\mu \mathrm{mol} \text { quanta m} \mathrm{m}^{-2} \mathrm{~s}^{-1}\right)^{-1}\right]\end{array}$} & \multicolumn{3}{|c|}{$\begin{array}{c}\text { Ek } \\
\mu \mathrm{mol} \text { quanta } \mathrm{m}^{-2} \mathrm{~s}^{-1}\end{array}$} \\
\hline & $100 \%$ & $10 \%$ & $1 \%$ & $100 \%$ & $10 \%$ & $1 \%$ & $100 \%$ & $10 \%$ & $1 \%$ \\
\hline June & 1.75 & 2.93 & 0.72 & 0.005 & 0.016 & 0.011 & 350 & 183 & 65 \\
\hline September & 5.63 & 8.66 & 2.02 & 0.012 & 0.035 & 0.026 & 469 & 247 & 78 \\
\hline November & 12.06 & 10.90 & 7.02 & 0.052 & 0.078 & 0.059 & 232 & 139 & 119 \\
\hline February & 6.39 & 12.69 & 6.59 & 0.019 & 0.115 & 0.060 & 336 & 110 & 109 \\
\hline May & 1.72 & 1.29 & 0.41 & 0.006 & 0.007 & 0.005 & 288 & 184 & 82 \\
\hline
\end{tabular}




\section{Discussion}

Phytoplankton studies have been carried out during the last decade in the 2 larger bays of the Gulf of California (Bahía de La Paz and Bahía Concepción). These studies have documented that primary productivity and phytoplankton community structure display seasonal changes, associated mainly with the occurrence of strong stratification during summer, and upwelling and water column mixing during winter (Martínez-López et al. 2001, Verdugo-Díaz et al. 2010). Biological responses to the physical forcing suggest that changes in phytoplankton community structure, as evidenced by increases of abundance in nanophytoplankton during summer conditions, could be related to a greater capacity of these cells to acquire and assimilate lower nutrient concentration during oligotrophic-water periods; allowing them to obtain a competitive advantage over larger cells (Fogg et al. 1986). Another factor, which possibly contributes to their dominance throughout the water column, may be related to a greater efficiency in their absorption and utilization of incident light compared to larger-sized cells, particularly at low irradiances (Agustí et al. 1994).

Photosynthesis-irradiance related parameters contain information of physiological seasonal changes of the phytoplankton community in Bahía de La Paz. These parameters according with their characteristics can be applied to specific examples and utilized to generate estimates of primary production in the study zone (ValdezHolguín et al. 1999). Phytoplankton photosynthesis rate variability in the ocean mainly depends of the quantity and quality of available light for the microalgae growth. Walsh \& Legendre (1983) did not notice significant differences in phytoplankton assimilation rates produced by variable irradiance, because photosynthetic capacity is not a direct function of light absorption (Sakshaug et al. 1997), it also depends on photo-acclimation. Marine microalgae exhibit several irradiance requirements in order to saturate their photosynthetic process and achieve their maximum productivity.

The P-E curve derived parameters generated in this study are high when compared to those reported for the central region of the Gulf of California (Gaxiola-Castro et al. 1999, Valdéz-Holguín et al. 1999), but similar to values registered around the large islands (Tiburón \& Ángel de la Guarda) in the northern Gulf (Alvarez-Borrego \& GaxiolaCastro 1988) as well as for a subtropical coastal lagoon of the Baja California Peninsula (Montes-Hugo \& AlvarezBorrego 2003). It seems that oceanographic conditions at
Bahía La Paz support high values of primary and secondary productivity (Jiménez-Illescas 1994, MartínezLópez et al. 2001, De Silva-Dávila \& Palomares-García 2002), making it one of the most productive zones of the Gulf.

Nutrient concentrations recorded in this study are consistent with those reported by Reyes-Salinas et al. (2003) and Cervantes-Duarte et al. (2005) for Bahía de La Paz. They described low nitrate concentrations in the upper euphotic zone during the entire year, which declined during the summer period. In our study we found high correlation between the values of $\mathrm{P}_{\mathrm{m}}$ and nitrate concentration (data not shown). Gaxiola-Castro et al. (1999) established that an increase in nutrient concentration is not necessarily correlated with an increase in $\mathrm{P}_{\mathrm{m}}$, because changes of this photosynthetic parameter are also a function of variations in growth irradiance controlled by stratification or mixing in the water column.

The observed values of maximum photosynthesis showed low variability during the studied period. Despite the low frequency of obtained data, which limits us to contrast statistically, it is clear that conditions of the water column play a central role in the magnitude of photosynthesis rate. Because of this, we consider very useful a mean value of $3.6 \mathrm{mg} \mathrm{C} \mathrm{m}^{-3} \mathrm{~h}^{-1}$ as representative of stratified conditions, $9.3 \mathrm{mg} \mathrm{C} \mathrm{m}^{-3} \mathrm{~h}^{-1}$ for homogeneity conditions, and $1.1 \mathrm{mg} \mathrm{C} \mathrm{m}^{-3} \mathrm{~h}^{-1}$ for the transitional periods. The lowest observed variability, especially during the stratified water column, may be associated to acclimation or tolerance ranges of phytoplankton in the face of environmental fluctuations that modify its photosynthetic parameters (Coté \& Platt 1983). Besides irradiance, chlorophyll cell-quantity or concentration (first order factor) in phytoplankton community is considered as the most influential in the variability of parameters derived from P-E curves (Cullen et al. 1992, Marañon \& Holligan 1999).

Under the same scheme, for the results corresponding to maximum photosynthetic efficiency at low irradiances, we suggest a value of $0.017 \mathrm{mg} \mathrm{C} \mathrm{m}^{-3} \mathrm{~h}^{-1}$ ( $\mu \mathrm{mol}$ quanta $\left.\mathrm{m}^{-2} \mathrm{~s}^{-1}\right)^{-1}$ as representative of stratification conditions; and an average value when the water column is homogeneous of $0.06 \mathrm{mg} \mathrm{C} \mathrm{m}^{-3} \mathrm{~h}^{-1}$ ( $\mu$ mol quanta $\left.\mathrm{m}^{-2} \mathrm{~s}^{-1}\right)^{-1}$. As the change is gradual between both conditions, the value that represents the transition period is $0.006 \mathrm{mg} \mathrm{C}$ $\mathrm{m}^{-3} \mathrm{~h}^{-1}$ ( $\mu$ mol quanta $\left.\mathrm{m}^{-2} \mathrm{~s}^{-1}\right)^{-1}$. The understanding of variability of this phytoplankton physiological indicator 
is important because its represents the trend of phytoplankton towards equilibrium between the light phase and dark reactions of photosynthesis; like equilibrium between quanta absorption for photosystem II and the electrons transported from water in order to reduce carbon dioxide (Escoubas et al. 1995, Sakshaug et al. 1997). Regarding this, Tilzer (1993) discussed the importance of understanding its magnitude and variability, as he defined it as a function of the number of photosynthetic units or reaction centers and antenna pigments.

Light saturation index parameter $\left(\mathrm{E}_{\mathrm{k}}\right)$ showed a marked correlation with depth, while the extent of temporal variation was lower. Considering these observations, we suggest an average of $335 \mu \mathrm{mol}$ quanta $\mathrm{m}^{-2} \mathrm{~s}^{-1}$ as the irradiance that saturates the phytoplankton photosynthetic process at ocean surface. Despite the relatively low value of $E_{k}$ in this case, we did not observe photoinhibition -a decline process in quantum efficiency caused by both irradiance and increasing temperature (Anderson et al. 1997). It has been observed that in natural environments like the Gulf of California, surface phytoplankton shows no photoinhibition, even at irradiances as high as $1.400 \mu \mathrm{mol}$ quanta $\mathrm{m}^{-2} \mathrm{~s}^{-1}$ (ValdezHolguín et al. 1999).

From phytoplankton samples collected at $10 \%$ and $1 \%$ surface irradiance levels, maxima photosynthesis reach saturation at $173.2 \mu \mathrm{mol}$ quanta $\mathrm{m}^{-2} \mathrm{~s}^{-1}$ and $90.8 \mu \mathrm{mol}$ quanta $\mathrm{m}^{-2} \mathrm{~s}^{-1}$, respectively. During each stratified period, a difference between levels was observed. This could be related with density differences which arguably propitiate that phytoplankton cells remain at the same depth, which in turn may allow better cell photoacclimation (Ley 1980, Falkowski 1983). On the other hand, during months of homogeneous water column, phytoplankton communities at the edge of euphotic zone may move upwards and acclimate accordingly to higher irradiances (Falkowski 1983), producing the observed uniformity between the $E_{k}$ values corresponding to irradiance levels of 10 and $1 \%$ of surface irradiance. It is well known that phytoplankton photoacclimation processes occur within time intervals varying from hours to days (Ley 1980), according to requirements and pigment structure of the species existent in the communities (Bidigare et al. 1990, Falkowski \& La Roche 1991). There are 2 main strategies for phytoplankton photoacclimation to dynamic irradiance regimes: 1 ) increments in photosynthetic unit's size, and 2) increase in the number of photosynthetic units. The physiologic mechanisms that occur at cellular level in adaptation to low irradiances comprise both, with a decrease in the numbers of photosynthetic units, and increase in the cell chlorophyll- $a$ (Ley 1980). In the same way, cells exposed to high photonic densities may resort to the xanthophylls cycle. Under such conditions, photon excess in the antenna unit is reflected as violaxanthin transformation into zeaxanthin helping to the dissipation of excessive energy (Hall 1994).

Hydrographic conditions at La Paz Bay maintain a stratified system from June to September, while in the period between November to February water-column remains homogeneous. Gaxiola-Castro et al. (1999) suggested that both, high water column stratification and mixing lead to low values in the water-column averaged photosynthetic parameters. Phytoplankton community react to this variability, with dinoflagellates and nanophytoplankton being more abundant during stratified conditions, while diatoms reach greater occurrence during the months of homogeneous water column (data not shown). In the same approach, the photosynthetic parameters as indicators of phytoplankton physiologic response in the expression of environmental variability show a relationship between its values and the prevailing environmental conditions. Despite the low frequency of experimental data, this study provides important representative values for $\mathrm{P}_{\mathrm{m}}$ and $\alpha$ at different oceanographic conditions in the water column. Likewise, representative values of $E_{k}$ were proposed for phytoplankton sampled communities at different irradiance levels. Our approach is based on backgrounds suggesting a closed relationship between water column physical stability and photosynthetic parameters for the southern Gulf of California phytoplankton.

\section{AcKnowledgments}

Funding was received from the Dirección de Estudios de Posgrado e Investigación, Instituto Politécnico Nacional (Grant SIP 990496). G.V.D and A.M.L. were supported by COFAA (Comisión de Operación y Fomento de Actividades Académicas) and EDI fellowships from the Instituto Politécnico Nacional of México. Partial funding was also provided to G.G.C. by the CICESE's Division of Oceanology and the project SEMARNAT-CONACYT2008-CO1-107267. G.G.C. is grant holder of the Sistema Nacional de Investigadores (SNI-CONACYT).

\section{LITERATURE CITED}

Agustí S, S Enríquez, H Frost-Chrstensen, K Sand-Jensen \& CM Duarte. 1994. Light harvesting among photosynthetic organisms. Functional Ecology 8: 273-279. 
Álvarez -Borrego S. 2011. Elements of support to estimate total and new primary production in the Gulf of California based on satellite data. Hidrobiológica 21: 281-292.

Álvarez-Borrego S \& G Gaxiola-Castro. 1988. Photosynthetic parameters of northern Gulf of California phytoplankton. Continental Shelf Research 8: 37-47.

Anderson JM, YI Park \& WS Chow. 1997. Photoinactivation and and photoproctection of photosystem II in nature. Physiology Plantarun 100: 214-223.

Babin M, A Morel \& R Gagnon. 1994. An incubator designed for extensive and sensitive measurements of phytoplankton photosynthetic parameters. Limnology and Oceanography 39(3): 694-702.

Balech E. 1988. Los dinoflagelados del Atlántico Sudoccidental. Publicación Especial, Instituto Español de Oceanografía 1: 88-310.

Bidigare RR, J Marra, TD Dickey, R Iturriaga, KS Baker, RC Smith \& H Pak. 1990. Evidence for phytoplankton succession and chromatic adaptation in the Sargasso Sea during spring 1985. Marine Ecology Progress Series 60: 113-122.

Brown J, A Colling, D Park, J Phillips, D Rhothery \& J Wrigth. 1989. Light and sound in seawater. In: Bearman G (ed). Seawater: its composition, properties and behavior, pp. 60- 85. The Open University, Great Britain.

Cervantes-Duarte R, G Verdugo-Díaz \& JE ValdezHolguín. 2005. Modelo estacional de producción primaria estimada mediante fluorescencia natural en una región costera del Golfo de California, México. Hidrobiológica 15(1): 7987.

Coté B \& T Platt. 1983. Day-to-day variations in the springsummer photosynthetic parameters of coastal marine phytoplankton. Limnology and Oceanography 28: 320344.

Coté B \& T Platt. 1984. Utility of the light-saturation curve as an operational model for quantifying the effects of environmental conditions on phytoplankton photosynthesis. Marine Ecology Progress Series 18: 57-66.

Cruz-Orozco R, A Mendoza-Maravillas \& C MartínezNoriega. 1989. Profundidades y formas de la Bahía de La Paz. Geonotas 1: 1-2. UABCS. México.

Cullen JJ, X Yang \& HL McIntyre. 1992. Nutrient limitation and marine photosynthesis. In: Falkowski PG \& AD Woodhead (eds). Primary productivity and biogeochemical cycles in the sea, pp. 68-88. Plenum Press, New York.

Cupp EE. 1943. Marine plankton diatoms of the West Coast of North-America. Bulletin of the Scripps Institute of Oceanography 5: 1-238.

De Silva-Dávila R \& JR Palomares-García. 2002. Distributional pattern of the euphausiid community in Bahía de La Paz, B.C.S., México. In: Hendrickx ME (eds). Contributions to the study of east Pacific crustaceans 1: 109-129.
Dower KM \& MI Lucas. 1993. Photosynthesis-irradiance relationships and production associated with a warm-core ring shed from the Agulhas Retroflection south of Africa. Marine Ecology Progress Series 95: 141-154.

Escoubas J, M Lomas, J La Rooche \& P Falkowski. 1995. Light intensity regulation of cab gene transcription is signalled by the redox state of the plastoquinone pool. Proceedings of the Natural Academy of Science 92: 1023710241.

Falkowski PG \& JA Raven. 1997. Aquatic photosynthesis, 375 pp. Blackwell Science, Malden.

Falkowski PG \& J La Roche. 1991. Acclimation to spectral irradiance in algae. Journal of Phycology 27: 8-14.

Falkowski PG. 1983. Light shade adaptation and vertical mixing of marine phytoplankton. A comparative field study. Plant Physiology 66: 592-595.

Fogg GE. 1986. Picoplankton. Proceedings of the Royal Society of London 228: 1-30.

Gaxiola-Castro G, S Álvarez-Borrego, MF LavínPeregrina, A Zirino \& S Najera-Martínez. 1999. Spatial variability of the photosynthetic parameters and biomass of the Gulf of California phytoplankton. Journal of Plankton Research 21: 231-245.

Hall Do \& KK Rao. 1994. Photosynthesis, 211 pp. Cambridge University Press, Great Britain.

Hasle GR. 1978. Using the inverted microscope. In: Sournia A (ed). Phytoplankton manual, pp. 191-196. UNESCO, Paris.

Hasle GR \& EE Syvertsen. 1996. Marine diatoms. In: Tomas CR (ed). Identifying marine diatoms and dinoflagellates, pp. 5-385. Academic Press, San Diego.

Hustedt F. 1930. Bacillariophyta In: Pascher A (ed). Süßwasserflora Mitteleuropas 10: 1-466. Fischer, Jena. [Reprint 1976 of the above: Königstein: Koeltz]

Hustedt F. 1959. Die Kieselalgen Deutschland, Österreichs und der Schweiz. In: Rabenhorst (ed). Kryptogamen-Flora von Deutschland, Österreichs und der Schweiz, Band VII, 2: 1-845 Teil. Koeltz Scientific Book (Reimp. 1991), Leipzig.

Jassby AD \& T Platt. 1976. Mathematical formulation of the relationship between photosynthesis and light for phytoplankton. Limnology and Oceanography 21: 540-547.

Jiménez-Illescas AR, M Obeso-Nieblas, M AlatorreMendieta \& S Troyo-Dieguez. 1994. Hidrología de la Bahía de La Paz. Oceanología 1(2):115-131.

Ley AC. 1980. The distribution of absorbed light energy for algal photosynthesis. In: Falkowski PG (ed). Primary productivity in the sea, pp. 59-82. Plenum Press, New York.

Licea-Durán S. 1974. Sistemática y distribución de diatomeas de la Laguna de Agiabampo, Son./Sin., México. Anales del Centro de Ciencias del Mar y Limnología UNAM 1: 99157. 
Marañon E \& PM Holligan. 1999. Photosynthetic parameters of phytoplankton from 50' N to 50' S in the Atlantic Ocean. Marine Ecology Progress Series 176: 191-203.

Martínez-López A, R Cervantes-Duarte, A Reyes-Salinas \& JE Valdez-Holguín. 2001. Cambio estacional de clorofila a en la Bahía de La Paz, B.C.S., México. Hidrobiológica 11(1): 45-52.

Montes-Hugo MA \& S Álvarez-Borrego. 2003. Spatial variation of photosynthetic parameters of phytoplankton in a subtropical coastal lagoon. Estuarine, Coastal and Shelf Science 56: 517-525.

Murray D \& H Schrader. 1983. Distribution of silicoflagellates in plankton and core type samples from the Gulf of California. Marine Micropaleontology 7: 517-539.

Parsons TR, Y Maita \& CM Lalli. 1984. A manual of the chemical and biological methods for seawater analysis, 173 pp. Pergamon Press, Oxford.

Pesantes F. 1978. Dinoflagelados del Golfo de Guayaquil. Boletín del Instituto de Oceanografía. de la Armada, INOCAR 2(2): 1-98.

Platt T \& S Sathyendranath. 1988. Oceanic primary production: Estimations by remote sensing at local and regional scales. Science 241: 1613-1620.

Reyes-Salinas A, R Cervantes-Duarte, RA Morales-Pérez \& JE Valdez-Holguín. 2003. Variabilidad estacional de la productividad primaria y su relación con la estratificación vertical en la Bahía de La Paz, B.C.S. Hidrobiológica 13(2): 103-110.

Sakshaug E, A Bricaud, Y Dandonneau, PG Falkowski, DA Kiefer, L Legendre, A Morel, J Parslow \& M Takahashi. 1997. Parameters of photosynthesis: definitions, theory and interpretation of results. Journal of Plankton Research 19: 1637-1670.
Schiller J. 1933. Dinoflagellates (Peridineae) in monographischer Behandlung teil 2. Rabenhorsts Kryptogamen-Flora, Leipzig 10: 1-598.

Schrader H, N Pisias \& G Cheng. 1986. Seasonal variation of silicoflagellates in phytoplankton and varved sediments in the Gulf of California. Marine Micropaleontology 10: 207-233.

Simpson JH \& JR Hunter. 1974. Fronts in the Irish Sea. Nature 250: 404-406.

Steemann-Nielsen E. 1952. The use of radio-active carbon $\left({ }^{14} \mathrm{C}\right)$ for measuring organic production in the sea. Journal du Conseil 18: 117-140.

Steidinger KA \& K Tangen. 1996. Dinoflagellates. In: Tomas CR (ed). Identifying marine diatoms and dinoflagellates, pp. 387-598. Academic Press, San Diego.

Taylor FJR. 1976. Dinoflagellates from the International Indian Ocean Exhibition. A report on material collected by the R VF. ‘Anton Bruun' 1963-1964. Bibliotheca Botany 132: 1-134.

Tilzer MM, C Hase \& EI Conrad. 1993. Estimation of in situ primary production from parameters of the photosynthesislight curve obtained in laboratory incubators. ICES Marine Science Symposium 197: 181-195.

Valdez-Holguín JE, S Álvarez-Borrego \& CC Trees. 1999. Caracterización espacial y temporal de los parámetros fotosintéticos del fitoplancton del Golfo de California. Ciencias Marinas 25(4): 445-467.

Verdugo-Díaz, G, A Martínez-López \& I Gárate-Lizárraga. 2010. Ecological indicators of the phytoplankton community structure in Bahía Concepción, México. Oceánides 25(2): 95-102.

Walsh P \& L Legendre. 1983. Photosynthesis of natural phytoplankton under high frequency light fluctuations simulating those induced by sea surface waves. Limnology and Oceanography 28(4): 688-697.

Received 11 December 2011 and accepted 8 November 2012

Associate Editor: Mauricio Landaeta D. 